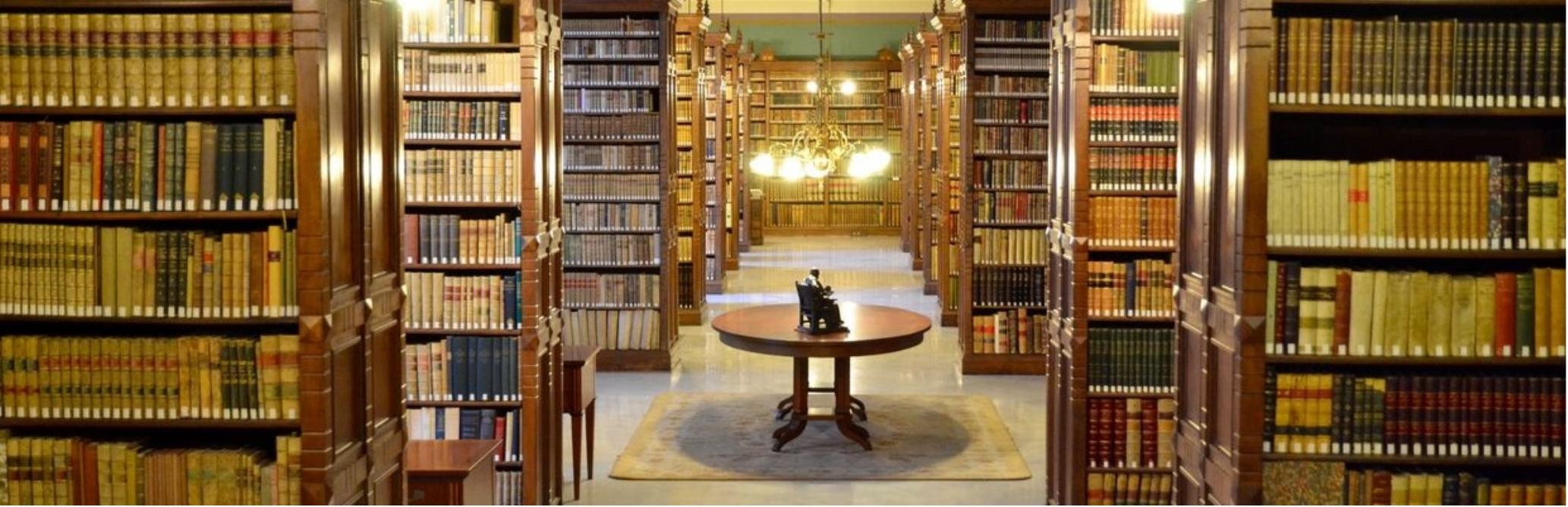




\section{JOSHA - Journal of Science Humanities and Arts Editorial Volume 6 Issue 7}

The current issue of the Josha Journal is dominated by the awards ceremony on July 6, 2019. Eight Demetrios Prizes and three Pythagoras Prizes were presented by the International Academy of Sciences, Humanities, and Arts at a successful concert and literature evening. In addition to the prize money, the international prize winners will also be able to publish their qualification papers in the Journal. The theses published in the journal the last weeks are bachelor, master and doctoral theses by young scientists. The spectrum ranges from philosophy and cultural studies to machine learning and medical work. The Pythagoras prizes went to the youth big band "Swing Kids", the poetess Zazie-Charlotte Pfeiffer and the singer Marie Brendle. All of them presented their performances at the award ceremony. Although no all of the winners were able to attend this evening, they have prepared a short video for all the readers of the Journal with an excellent explanation concerning the topics of their works. All these videos have direct access to YouTube just by clicking on the button "Watch Video".

\section{\pm Download PDF}

Watch Video

\section{VISUAL ARTS, ARCHITECTURE, AND LITERATURE}

The first work deals with the representation of intergenerational trauma in the film "La teta asustada" by Claudia Llosa. Yasemin Soydan, a student from Freiburg, was awarded a Demetrios Prize for this admission thesis. Maria Sandoval's bachelor thesis is thematically close and is dealing with the film confrontation of the MexicanAmerican border entitled Migration as a theme in Latin American cinema. Border between Mexico and the United

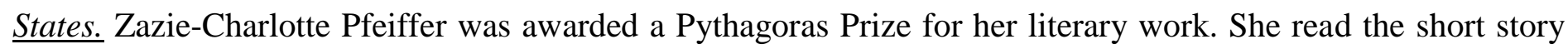
"The Wedding" during the award ceremony.

MEDICINE AND MACHINE LEARNING

Julia Pinter, a German student, is focusing her research on cancer and has written her bachelor thesis "Optimizing T-Cell Culture in Microfluidic Devices" on a new therapeutic approach with CAR-T cells. Nikolas Woitzik's dissertation is part of an interdisciplinary project between medicine and machine learning. It analyses the patient's discharge summaries with the help of information retrieval and natural language processing methods. The third winner of this area is from Colombia, and presented us his research entitled "Functional outcomes of radial head 
fractures type III and IV, after management with arthroplasty or internal fixation.". His work covers everything related to radial cup fractures, which account for $4 \%$ of anatomical fractures.

\section{PHILOSOPHY AND SOCIAL}

Three works awarded a Demetrios Prize come from the field of philosophy. Federico Abal's work deals with the current debate on torture and has been entitled "Torture: permissibility, real-world and legislation". The final work of Joaquín Campodónico treats a more pleasant subject. He writes about The tragic pathos of the young Nietzsche in connection with art and life in the "birth of tragedy". Another winner, from Argentina, presented in his dissertation the "Romantic Love from a Marxian Perspective", where Guido Selim Arditi deals with the emergence and the future of romantic love from a Marxist perspective.

In our current issue, not only scientific publications awarded with a prize appear. Further works of taking also part of the Philosophy and Social Affairs section. Mike Omilusi: "The Psycho-Political Underpinnings of Presidential Speeches: President Buhari's Three Selected Speeches to Countrymen", Sunday Akindele with "Voters inducement techniques and the electoral process in Nigeria: a case of the 2017 Osun west senatorial byeelection" and, in the field of Life Sciences and Medicine, we present you the work of Alahí Dana Bianchini with a scientific galaxy lacking replications: on Ioannidis' "In scientific method we don't just trust or why replication has more value than discovery".

We are happy to carry on a successful way with all your support and hope to have a wonderful Sommer overflowing with endless interesting articles from all over the world. Together, we have achieved so much exile in such a short time. Therefore, we thank you and promise to continue to work to connect more authors around the world and continue to share important knowledge, because the knowledge that is not communicated is wasted knowledge!

The Editorial Board and everybody in JOSHA would like to thank our readers and authors for supporting this project. We wish all our readers a joyful reading experience at JOSHA!

Table of content: http://josha-journal.org/en/issues

Stephan Seiler on behalf of the JOSHA Team 